\title{
Improving Prospective Primary School Teachers' Mental Models through Implementation of CDOI Supported by Multimode Visualization
}

\author{
Neni Hermita ${ }^{1, *}$, Mahmud Alpusari ${ }^{1}$, Eddy Noviana ${ }^{1}$, Zetra Hainul Putra ${ }^{1}$, Nur Islami ${ }^{2}$, Hutnal Basori ${ }^{3}$, \\ Andi Suhandi ${ }^{4}$, Achmad Samsudin ${ }^{4}$ \\ ${ }^{1}$ Program Studi PGSD, Universitas Riau, Indonesia \\ ${ }^{2}$ Program Studi Pendidikan IPA, Universitas Riau, Indonesia \\ ${ }^{3}$ Department Pendidikan Fisika, Universitas Pendidikan Indonesia, Indonesia \\ ${ }^{4}$ Program Studi Pendidikan IPA, Universitas Pendidikan Indonesia, Indonesia
}

Received November 14, 2019; Revised December 20, 2019; Accepted December 25, 2019

Copyright@2020 by authors, all rights reserved. Authors agree that this article remains permanently open access under the terms of the Creative Commons Attribution License 4.0 International License

\begin{abstract}
This study aims to improve the mental model of prospective primary school teacher related to the concept of boiling through the implementation of the conceptual development-oriented instruction (CDOI) model assisted by multimode visualization. This research was conducted using the pre-experimental method with the design of one group pretest-posttest. The subjects of the study were 36 the prospective primary school teachers, consisting of 20 female and 16 males. The research location is one of the universities in Riau province. The instrument used for collecting data is the conceptual understanding level test related to the concept of boiling in the form of open-ended that cover three parts of the question, which has previously been validated and tested for its reliability. The results of this study indicate that the implementation of the CDOI model assisted by multimode visualization has high effectiveness in facilitating the achievement of the scientific mental model, and no gender bias on achieving scientific mental models by the prospective primary school teacher.
\end{abstract}

Keywords CDOI Model, Mental Model, Boiling Concept

\section{Introduction}

One of the main competencies that primary school teachers must possess is professional competence which includes teachers' fully and deeply understanding of subject matter. This competency must be abused when they are educating primary school teacher institutions.
Misunderstanding or misconceptions occur if the teacher does not comprehend subject matter comprehensively. An understanding of a subject matter in elementary teacher candidates can be seen in the mental models they have. The scientific mental model reflects a good and comprehensive conceptual understanding. Mental model is a description of students' thoughts about a situation that is delivered with an explanation and reasons related to a particular case [1], [2]. In addition, Gentner \& Stevens [3] also said that the mental model is a representation of someone in understanding and explaining a phenomenon. Wang \& Barrow found that mental models support the understanding and explanation of one's logic spontaneously when formed in dealing with specific situations; mental models are stored as long-term memory [4]. When students learn new concepts in the form of text or pictures and make connections between information received, mental models will form [5], [6]. The identical object was communicated by Stains \& Sevian that mental models can be shaped after somebody is encrustation a particular problem [7]. According to Gentner \& Stevens [4], mental models are formed from a certain process and condition repeatedly. Based on some of the opinions above, it was concluded that mental models vary according to one's experience and understanding.

Unfortunately, the results of field study related to the concepts in the subject matter of change in the state of matter, show the situation was not encouraging, most of the prospective primary school teachers at one of the universities in Riau were still in the category of synthetic and initial mental models. This situation is thought to be closely related to the lecture process carried out for the basic concept of science subjects that still use traditional methods. 
The lecture method in the traditional approach does not facilitate the achievement of mental models for the scientific category. The traditional approach to lectures consists of the following steps; express concepts with words, defining concepts, identifying and distinguishing abilities needed to understand definitions in ensuring students find cases that are related and not related to the idea. In learning concepts, this traditional approach is not sufficient [8]. Because to understand concepts and the relationships between ideas, it is not enough to identify and memorize the concepts. Learning takes place monologically in a traditional approach. In a monologue, lecturers dominate the class and knowledge is transmitted from lecturer to students, so students tend to memorize

Instead, an appropriate learning environment must be created so students can learn to find scientific knowledge such as scientists. Thus, students do not need to memorize knowledge because concepts are obtained through the learning process. Learning must be done by involving interaction between teacher and students and interaction between students and students in constructing an idea.

One of the teaching approaches that are regularly used for conceptual construction is the conceptual development approach (CDA). There are several educations conducted by preceding researchers nearly the use of the conceptual development approach in physics teaching, which is what was done by Koponen \& Huttunen [10] and Baweja [11]. Implementation in lecture, the CD approach is represented in the conceptual development-oriented instruction model or abbreviated as CDOI models.

In physics teaching, physical content that comprehends microscopic phenomena is habitually difficult for students to understand. Explanation of these microscopic phenomena requires the support of visual media that can model invisible microscopic phenomena into a phenomenon that can be seen by the eye [12]. Most of physics teaching needs understanding at three (3) levels of representation, namely: representation of macroscopic, sub-microscopic representations, and symbolic representations [13]. In order to soundly understand the concept of physics, students' requirement to understand the concepts of physics at three levels of representation. Physics teaching must begin with macroscopic and symbolic representations, and then proceed with submicroscopic representations [14]. Because the concept of boiling includes microscopic and macroscopic physics quantity, so to improve learners' understanding of this conception, three stages of representation need in the learning process of this concept. The procedure of three stages of representation in this CDOI model is recognized in the formula of the use of multimode visualization, such as: video about boiling phenomena, microscopic virtual simulations about boiling, and dynamic analogy.

This research was conducted to get a depict of the effectiveness of using the CDOI model supported by multimode visualization in facilitating the achievement of the scientific mental model by prospective primary school teacher related to the concept of boiling. Categories of mental models reviewed in this study are scientific mental models, synthetic mental models and initial mental models. Scientific mental model is a category of mental models that describe students 'perceptions or conceptions about a phenomenon that is fully in accordance with scientific concepts, synthetic mental models are categories of mental models that describe students' perceptions or conceptions about a phenomenon that are only partially in accordance with scientific concepts, while the initial mental model is a category of mental models that describe students' perceptions or conceptions about a phenomenon that is totally incompatible with scientific concepts, or contains alternative conceptions in their perceptions.

\section{Methods}

\subsection{Research Design}

This study uses a pre-experimental method with one group pretest-posttest design. Research subjects numbered 36 prospective primary school teachers consisting of 20 female students and 18 male students at Universitas Riau.

Table 1. Evaluation Rubric for Descriptive Responses

\begin{tabular}{|c|c|c|}
\hline $\begin{array}{c}\text { Levels of } \\
\text { Understanding (LU) }\end{array}$ & Score & Criteria \\
\hline $\begin{array}{c}\text { Sound Understanding } \\
\text { (SU) }\end{array}$ & 4 & $\begin{array}{c}\text { Responses containing all } \\
\text { components of the } \\
\text { scientifically accepted } \\
\text { response }\end{array}$ \\
\hline $\begin{array}{c}\text { Partial Understanding } \\
\text { (PU) }\end{array}$ & 3 & $\begin{array}{c}\text { Responses containing some } \\
\text { components of the } \\
\text { scientifically accepted } \\
\text { response }\end{array}$ \\
\hline $\begin{array}{c}\text { Partial Understanding } \\
\text { with Altemative } \\
\text { Conception (PU-AC) }\end{array}$ & 2 & $\begin{array}{c}\text { Responses showing that the } \\
\text { concept is understood but also } \\
\text { containing altemative } \\
\text { conceptions }\end{array}$ \\
\hline $\begin{array}{c}\text { Altemative Conception } \\
\text { (AC) }\end{array}$ & 1 & $\begin{array}{c}\text { Scientifically incorrect } \\
\text { responses containing illogical } \\
\text { or incorrect information }\end{array}$ \\
\hline No Understanding(NU) & 0 & $\begin{array}{c}\text { Blank, irrelevant, or unclear } \\
\text { responses }\end{array}$ \\
\hline
\end{tabular}

\subsection{Instrument}

The conceptual understanding (CU) test related to boiling concepts in open-ended form is an instrument used in gathering data, covering three fragments of the question. The BCUTest (Boiling Conceptual Understanding Test). Question-1(Q1) needs an answer in the form of a verbal explanation about definition of boiling, question-2 (Q2) needs answers in the form of verbal explanations about physical mechanism of boiling, and question-3 (Q3) needs a response in the form of a state of the representation of microscopic pictorial of the physical mechanism of the boiling phenomena. The item test for testing the students' level of understanding related to the concept of boiling is presented in Figure 1. 
No. 1.

Q1. What is boiling? Please explain!

Q2. Explain how water can boil when absorbing heat (heated)! Q3. Illustrate the state of water molecules $\left(\mathrm{H}_{2} \mathrm{O}\right)$ during the boiling process in the representation of microscopic pictorial!

Figure 1. Item of BCUTest

Before being used in research, BCUTest is validated and tested for reliability. Based on the results of expert judgment, the instruments used in this study have construct and content validity. While based on the results of the reliability analysis using the test-retest method, the instrument has a reliability coefficient of 0.82 which indicates that the BCUTest used in this study has a high reliability.

\subsection{Data Analysis}

For scoring Conceptual understanding test consists of three questions (Q1, Q2, and Q3). Assessment for questions 1 and 2 (Q1, Q2) requires answers in the form of verbal descriptions, Q1 and Q2 use the rubric recommended by Kurnaz [14]. Images are needed to analyze students' answers to questions (Q3), Rubrics have been developed based on Abraham's rubric for descriptive responses [15], and the initial analysis of answers provided for Q3 is done through data collection tools based on studies conducted by Saglam Arslan [16] in Table 2.

Table 2. Evaluation Rubric for Visual Responses

\begin{tabular}{|c|c|c|}
\hline $\begin{array}{c}\text { Levels of Understanding } \\
\text { (LU) }\end{array}$ & Score & Criteria \\
\hline Correct Depicting (CD) & 4 & $\begin{array}{c}\text { Drawings reflecting all } \\
\text { components of the scientific } \\
\text { depiction }\end{array}$ \\
\hline $\begin{array}{c}\text { Partial Correct Depicting } \\
\text { (PCD) }\end{array}$ & 3 & $\begin{array}{c}\text { Drawings reflecting some } \\
\text { components of the scientific } \\
\text { depiction }\end{array}$ \\
\hline $\begin{array}{c}\text { Correct Drawings } \\
\text { reflecting also } \\
\text { Nonscientific Depicting } \\
\text { (CD-ND) }\end{array}$ & 2 & $\begin{array}{c}\text { Drawings reflecting } \\
\text { scientific or partial } \\
\text { scientific but also } \\
\text { nonscientific depictions }\end{array}$ \\
\hline Incorrect Depicting (ID) & 1 & $\begin{array}{c}\text { Drawings reflecting wholly } \\
\text { nonscientific depictions }\end{array}$ \\
\hline No Depicting (ND) & 0 & Blank \\
\hline
\end{tabular}

The category of mental models of each student is determined from the results of conceptual understanding related to boiling concepts was use guidelines in Table 3 [15].

\subsection{Model of Instruction}

The syntax of the CDOI model implemented in the teaching of boiling concept consists of seven stages of activity, namely: 1) identification of students' initial mental models, 2) student orientation to phenomena related to a context, 3) concept formation and content understanding construction using interactive demonstration methods, class discussions and frequently asked-questions, 4) monitoring the progress of students' conception, 5) conception reinforcement and enrichment, 6) reflection and follow-up teaching, and 7) identification of students' final model mental.

Table 3. Evaluation Rubric for Mental Models

\begin{tabular}{|c|c|c|}
\hline $\begin{array}{c}\text { Mental } \\
\text { Models } \\
\text { (MM) } \\
\text { Category } \\
\end{array}$ & Content & Criteria \\
\hline Scientific & $\begin{array}{l}\text { Perceptions which coincide } \\
\text { with scientific knowledge: } \\
\text { answers at level } 3 \text { (PU or } \\
\text { PCD) or } 4 \text { (SU or CD). }\end{array}$ & $\begin{array}{l}\text { Sker for question } \\
\text { A, B and C } \\
\text { everything is } \\
\text { high ( } 3 \text { or } 4)\end{array}$ \\
\hline Synthetic & $\begin{array}{l}\text { Perceptions which partially } \\
\text { coincide or do not coincide } \\
\text { with scientific knowledge. }\end{array}$ & $\begin{array}{l}\text { Skor for question } \\
\text { A, B and C } \\
\text { (some are high ( } 3 \\
\text { or } 4 \text { ) but some } \\
\text { are low (0 or } 1 \text { or } \\
2 \text { ) }\end{array}$ \\
\hline Initial & $\begin{array}{l}\text { Perceptions which do not } \\
\text { coincide with scientific } \\
\text { knowledge: answers at level } \\
0 \text { (NU or ND), } 1 \text { (AC or ID) } \\
\text { or } 2 \text { (PU-AC or CD-ND). }\end{array}$ & $\begin{array}{l}\text { Skor for question } \\
\text { A, B and C } \\
\text { everything is low } \\
(0 \text { or } 1 \text { or } 2)\end{array}$ \\
\hline
\end{tabular}

\section{Results}

The following is an example of the answers of prospective primary school teachers number 11 (P11) to BCUTest before and after participating in course with the CDOI model. The answer has been translated by researchers from Indonesian to English.

\section{Answer P11}

Before CDOI

A. Boiling is a turbulent state of water when heated due to the formation of many bubbles in the water that indicate a change in the form of looking liquid to gas.

B. When heated $\mathrm{H} 2 \mathrm{O}$ molecule bonds will break so that it produces gas in water.-

\section{After CDOI}

A. Boiling is a term used to change the form from water (liquid) to water vapor (gas) which occurs when water (liquid) absorbs heat (heated). The difference with vaporization lies in the position of the generation of water vapor. If in the process of evaporating, water vapor is released from the surface of the water, in the boiling process, water vapor is produced throughout the volume of water which is marked by the appearance of bubbles in the water that contains water vapor.

$B$. When the water is heated then a convection process will first occur to move the heat from the bottom of the heated water to the top (water surface) which occurs continuously until the 
surface of the water also rises in temperature. This convection process is accompanied by the process of release of water molecules from the surface of the water into the atmosphere (the process of evaporating). Over time the temperature at the bottom of the water and at the surface of the water will be almost the same or even the same. When this has been achieved, the convection process will stop because there is no temperature difference below and above the volume of water. Because water continues to absorb heat while the rotation process (convection) stops, then the heat absorbed will be used to break the bonds of $\mathrm{H} 2 \mathrm{O}$ molecules not only from the surface of the water but from all parts of the volume of water. $\mathrm{H} 2 \mathrm{O}$ molecules that are broken from bonds will be in the form of gas (water vapor). The presence of water vapor (gas) in the water will certainly form bubbles that rise from the bottom to the top and then burst into the atmosphere. And so on until the water turns into water vapor released into the atmosphere.

C. Draw the structure of $\mathrm{H}_{2} \mathrm{O}$ molecular bonds when the water boils.
Answer P11 before CDOI for question A gets a score of 2 , for question $B$ gets a score of 1 and for question $C$ gets a score of 0 because it doesn't give an answer. While the answer P11 after CDOI for question A gets a score of 4 , for question $\mathrm{B}$ gets a score of 4 as well as question $\mathrm{C}$ gets a score of 4 . Based on the scores obtained, then before CDOI P11 has a category of initial mental models, whereas after CDOI has a category scientific mental models. The scoring process is done for all students so that mental model categories can be identified for each student both before and after CDOI.

Table 4 shows the scores achieved by prospective primary school teacher for each part of the BCUTest question at the time before and after the implementation of CDOI model.

The mental model categories achieved by each prospective teacher related to the boiling concept were obtained from the scores in each section of the BCUTest questions. After the mental model categories achieved by each prospective teacher are known, the number of elementary school teacher candidates is calculated in each mental model category. Table 5 shows the quantity of students in each category of mental models related to the concept of boiling before and after the implementation of the CDOI model.

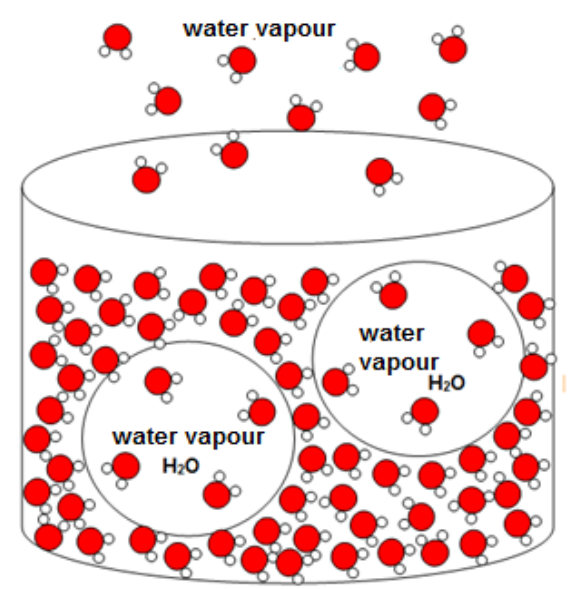


Table 4. The score for each part of question of BCUTest

\begin{tabular}{|c|c|c|c|c|c|c|c|}
\hline \multirow{2}{*}{ Prospective primary school teacher $(\mathrm{P})$} & \multicolumn{3}{|c|}{ Before CDOI } & \multirow{2}{*}{ Prospective primary school teacher (P) } & \multicolumn{3}{|c|}{ After CDOI } \\
\hline & Q1 & Q2 & Q3 & & Q1 & Q2 & Q3 \\
\hline $\begin{array}{l}F(-) \\
M(-)\end{array}$ & 3 & 3 & 3 & $\begin{array}{l}\text { F (P10, P11, P18) } \\
\text { M (P7, P15, P31) }\end{array}$ & 4 & 4 & 4 \\
\hline $\begin{array}{c}\mathrm{F}(\mathrm{P} 18) \\
\mathrm{M}(\mathrm{P} 7, \mathrm{P} 31)\end{array}$ & 3 & 2 & 1 & $\begin{array}{l}\text { F (P2, P27, P28) } \\
\text { M (P9, P19) }\end{array}$ & 4 & 3 & 4 \\
\hline $\begin{array}{c}\text { F (P2, P10, P20, P27, P28) } \\
\text { M (P9, P15, P19, P34 ) }\end{array}$ & 3 & 2 & 0 & $\begin{array}{l}\text { F (P20, P35) } \\
\text { M (P34) }\end{array}$ & 4 & 3 & 3 \\
\hline $\begin{array}{c}\text { F (P4, P35) } \\
\text { M (P17) }\end{array}$ & 3 & 1 & 1 & $\begin{array}{c}\text { F (P4, P13, P36) } \\
\text { M (P12, P17, P29) }\end{array}$ & 3 & 3 & 4 \\
\hline $\begin{array}{c}\text { F (P5, P13, P22, P26, P32) } \\
\text { M (P3, P12, P21, P25) }\end{array}$ & 3 & 1 & 0 & $\begin{array}{c}\text { F (P1, P5, P14, P22, P26, P32) } \\
\text { M (P3, P6, P21, P25, P33) }\end{array}$ & 3 & 3 & 3 \\
\hline $\begin{array}{c}\mathrm{F}(\mathrm{P} 36) \\
\mathrm{M}(\mathrm{P} 16) \\
\end{array}$ & 2 & 1 & 1 & $\begin{array}{c}\mathrm{F}(\mathrm{P} 8) \\
\mathrm{M}(\mathrm{P} 25) \\
\end{array}$ & 3 & 2 & 3 \\
\hline $\begin{array}{c}\text { F ( P11, P14, P30) } \\
\text { M (P24) }\end{array}$ & 2 & 1 & 0 & $\begin{array}{l}\text { F (P23, P30) } \\
\text { M (P16) }\end{array}$ & 3 & 2 & 2 \\
\hline $\begin{array}{c}\text { F (P8, P23) } \\
\text { M (P29, P33) }\end{array}$ & 2 & 0 & 0 & $\begin{array}{l}F(-) \\
M(-)\end{array}$ & 3 & 1 & 3 \\
\hline $\begin{array}{l}F(-) \\
M(-)\end{array}$ & 1 & 1 & 0 & $\begin{array}{l}F(-) \\
M(-)\end{array}$ & 2 & 2 & 2 \\
\hline $\begin{array}{l}\text { F (P1) } \\
\text { M (P6) }\end{array}$ & 1 & 0 & 0 & $\begin{array}{l}\mathrm{F}(-) \\
\mathrm{M}(-)\end{array}$ & 2 & 2 & 0 \\
\hline
\end{tabular}

Table 5. Quantity of prospective teacher in every mental model category about boiling concept before and after CDOI activity

\begin{tabular}{|c|c|c|c|c|c|c|c|c|c|}
\hline \multicolumn{5}{|c|}{ Before CD-CCOI } & \multicolumn{5}{|c|}{ After CD-CCOI } \\
\hline \multirow{2}{*}{$\begin{array}{c}\text { Category of Mental } \\
\text { Model }\end{array}$} & \multicolumn{2}{|c|}{$\begin{array}{c}\text { Quantity of } \\
\text { Prospective teacher }\end{array}$} & \multicolumn{2}{|c|}{ Percent (\%) } & \multirow{2}{*}{$\begin{array}{c}\text { Category of Mental } \\
\text { Model }\end{array}$} & \multicolumn{2}{|c|}{$\begin{array}{c}\text { Quantity of } \\
\text { Prospective teacher }\end{array}$} & \multicolumn{2}{|c|}{ Percent (\%) } \\
\hline & $\mathrm{F}$ & M & F & M & & $\mathrm{F}$ & M & $\mathrm{F}$ & $M$ \\
\hline Scientific & 0 & 0 & 0 & 0 & Scientific & 17 & 14 & 47 & 39 \\
\hline Synthetic & 13 & 11 & 36 & 31 & Synthetic & 3 & 2 & 8 & 6 \\
\hline Initial & 7 & 5 & 19 & 14 & Initial & 0 & 0 & 0 & 0 \\
\hline Total & 20 & 16 & 55 & 45 & Total & 20 & 16 & 55 & 45 \\
\hline
\end{tabular}

Table 5 above shows the changes between before and after the implementation of the CDOI model in the mental model category of prospective primary school teachers'. The quantity of prospective primary school teacher who achieve the category of scientific mental models increased while the quantity of prospective primary school teacher who achieve the category of synthetic and initial mental models decreased. The total quantity of prospective primary school teacher who change in their mental models towards the scientific mental model is $86 \%$ consisting of $47 \%$ female and $39 \%$ male, it is indicates that the application of the CDOI model supported by multimode visualization have a high effectiveness in improving the mental model of prospective primary school teachers related to the concept of boiling. The pattern of changes in the category of mental models achieved by prospective primary school teacher from before to after following the CDOI model is shown in Figure 2.
The high effectiveness of the use of the CDOI model in improving prospective primary school teachers' mental models, aside from using the conceptual development approach, also because of the presence of multimode visualization, which are very helpful in the process of description of physical content to include three levels of representation. The presence of multimode visualization can help visualize invisible microscopic phenomena into observable phenomena, so that these phenomena will be more easily understood by prospective primary school teacher. Siriswadi and Siriporn [18] said that physical phenomena/events would be easier to understand when students observed directly rather than students listening to lecturers and imagining it. The use of virtual simulation media can help students to understand physical phenomena down to the microscopic or sub-microscopic level [19, 20, 21, 22]. 


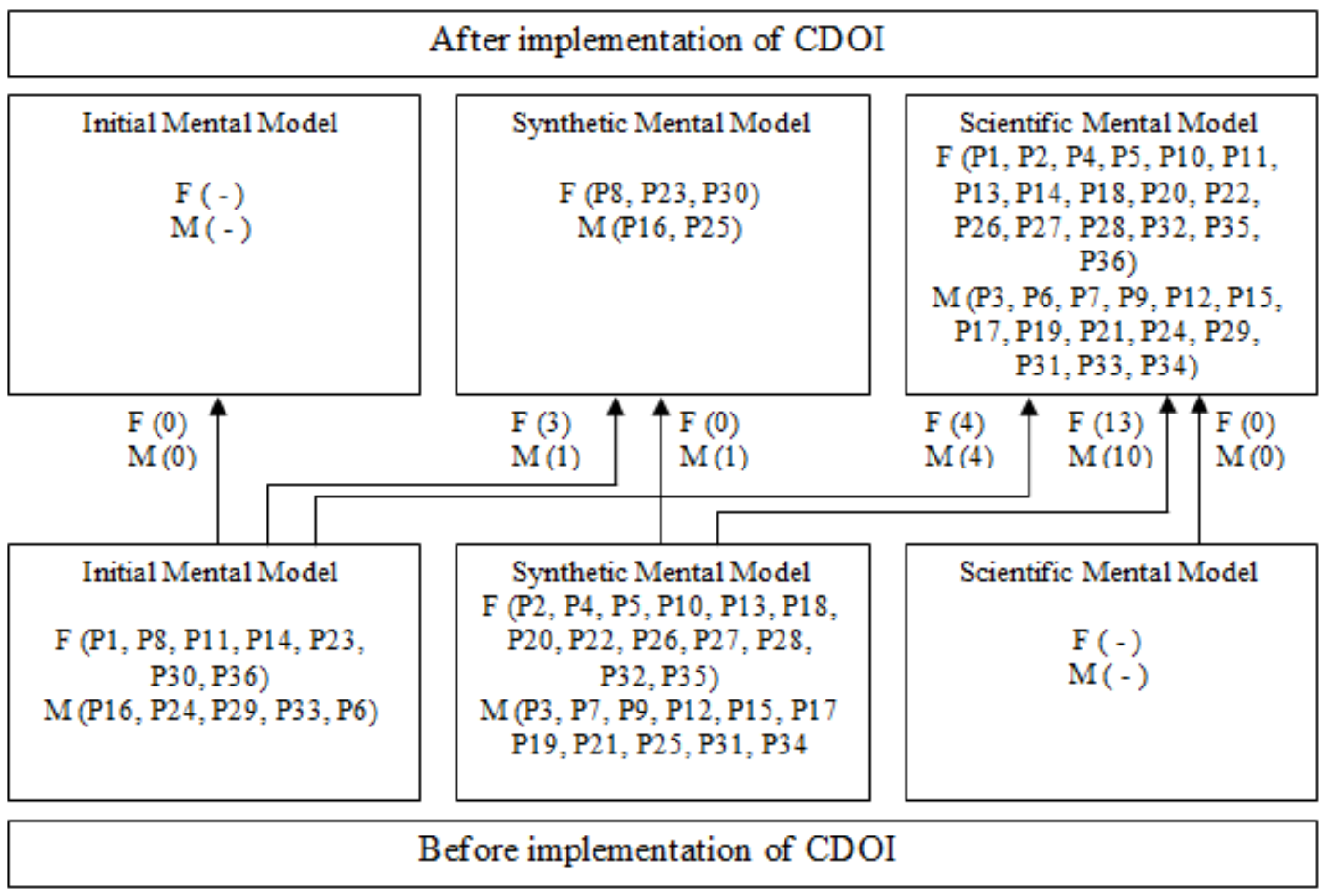

Figure 2. The pattern of changes in the category of mental models from before to after following the CDOI activity

\section{Discussion}

Related to the use of dynamic analogies in teaching physics concepts that contain microscopic phenomena. Harrison [23] describes that some abstract phenomena can only be taught adequately by using analogies, for example, in physical phenomena such as electric currents, pressures, atomic structures and others. Furthermore, Harrison and Treagust [24] also said that using analogies in learning can increase student confidence. Analogy plays an important role in significantly strengthening students' conceptual understanding and learning in science education [25, 26]. Analogy is often used to make abstract scientific concepts more understandable to students [27]. Because analogy is a way of matching newly learned knowledge with existing ones in students 'long-term memory [28], the use of analogies can improve students' conceptual understanding [29]. Some researchers have reported that when analogies are used in the teaching of physical concepts such as electricity[29], pressure [30,31], heat conduction and wave properties light [24], there are positive changes in the achievement of learning outcomes and an increase in understanding concepts and improving their attitudes towards the physics.

From Table 5, it can be seen that the quantity of female and male prospective teacher who reach the scientific mental model almost the same. These results show that the use of CDOI model supported by multimode visualization in teaching of boiling concept has a great effectiveness and efficiency in facilitating the realization of the scientific category of the mental model by female and male prospective teacher. The results showed that there was no gender bias in the use of CDOI model supported by multimode visualization in facilitating the achievement of the scientific mental model. Both female and male prospective teacher can improve their mental models from synthetic or initial categories to scientific categories. These indications that the procedure of CDOI model supported by multimode visualization can facilitate male and female prospective teacher in reaching a level of SU (sound understanding). This finding agrees with investigations found by several previous researchers, including; there is no gender bias in increasing understanding of physical concepts [32], scores obtained in physics learning did not differ significantly between male and female students [33], and students' scientific reasoning abilities are not significantly influenced by gender. This means that CDOI model supported by multimode visualization are suitable for use in teaching activity oriented to the construction of a sound and deep understanding of the concepts of both female and male prospective teacher.

\section{Conclusions}

Based on the findings in the field and the results of the study, it can be concluded that the application of the CDOI model supported by multimode visualization has high effectiveness in facilitating elementary school teacher candidates in achieving the category of scientific mental models. These show that the conceptual development process that leads to the formation of a comprehensive 
understanding of the concept of boiling in the minds of prospective elementary school teachers can be facilitated through the use of multimode visualization in the CDOI model. There is no gender bias in achieving a scientific mental model by secondary school teachers as the effect of using the CDOI model supported by multimode visualization.

\section{Acknowledgements}

Thanks to DRPM, Dirjen Ristekdikti Republik Indonesia for the support through the hibah PTUPT.

\section{REFERENCES}

[1] Johnson-Laird, P. N. (2013). Mental Models and Cognitive Change.Journal of Cognitive Psychology, 25(2), 131-138.

[2] Amalia, F. R., Ibnu, S., Widarti, H. R., \&Wuni, H. (2018). Students' Mental Models of Acid and Base Concepts Taught Using The Cognitive Apprenticeship Learning Model, JurnalPendidikan IPA Indonesia (JPII), 7 (2), 187-192.

[3] Gentner, D., \& Stevens, A. L. (Eds.). (2014). Mental models. Psychology Press.

[4] Wang, C. Y., \& Barrow, L. H. (2011). Characteristics and Levels of Sophistication: An Analysis of Chemistry Students' Ability to Think with Mental Models. Research in Science Education, 41(4), 561-586.

[5] Stains, M., \&Sevian, H. (2015). Uncovering Implicit Assumptions: A Large-scale Study on Students' Mental Models of Diffusion. Research in Science Education, 45(6), 807-840.

[6] Saptono, S., Isnaeni, W., \&Sukaesih, S. 2017. Undergraduate Students' Mental Model of Cell Biology, JurnalPendidikan IPA Indonesia (JPII), 6 (1), 145-152.

[7] Tümay, H. (2014). Prospective Chemistry Teachers’ Mental Models of Vapor Pressure. Chemistry Education Research and Practice, 15(3), 366-379.

[8] Çepni, S., Ayas, A., Johnson, D., \& Turgut, F. (1997). Fizik Öğretimi. YÖK/Dünya Bankası Milli Eğitimi Gelistirme Projesi Hizmet Öncesi Öğretmen Eğitimi, Ankara. (in Turkish) Reznitskaya, A. (2012). Dialogic teaching: Rethinking language use during literature discussions. The Reading Teacher, 65 (7), 446-456.

[9] Koponen, I. T., \& Laura Huttunen, L. (2013). Concept Development in Learning Physics: The Case of Electric Current and Voltage Revisited, Science \& Education 22(9), (2013), 2227-2254.

[10] Baweja, M (2015). Strategies to Improve Concept Development, International Journal of Science and Research (IJSR), Volume 6 Issue 3, March, 1746-1748

[11] Wibowo, F. C., Suhandi, A., Rusdiana, D., Samsudin, A., Darman, D. R., Faizin, M. N., Wiyanto, Supriyatman,
Permanasari, A., Kaniawati, I., Setiawan, W, Karyanto Y. Linuwih, S., Fatah, A., Subali, B., Hasani, A., Hidayat, S., (2017). Effectiveness of Dry Cell Microscopic Simulation (DCMS) to Promote Conceptual Understanding about Battery. Journal of Physics: Conf. Series 877, 012009.

[12] Davidowitz, B., Chittleborough, G., \& Murray, E. (2010). Student-Generated Submicro Diagrams: A Useful Tool for Teaching and Learning Chemical Equations and Stoichiometry. Chemistry Education Research and Practice, 11(3), 154-164.

[13] Cheng, M., \& Gilbert, J. K. (2009). Towards A Better Utilization of Diagrams in Research into the Use of Representative Levels in Chemical Education. In Multiple representations in chemical education (pp. 55-73). Springer, Dordrecht.

[14] Kurnaz, M. A., \&Eksi, C. (2015). An Analysis of High School Students' Mental Models of Solid Friction in Physics. Educational Sciences: Theory and Practice, 15(3), 787-795.

[15] Abraham, M. R., Williamson, V. M., \& Westbrook, S. L. (1994). A cross-age study of the understanding of five chemistry concepts. Journal of Research in Science Teaching, 31(2), 147-165.

[16] Sağlam Arslan, A. (2009). Cross-grade comparison of students' understanding of energy concepts. Journal of Science Education and Technology, 19(3), 303-313.

[17] Srisawasdi, N \&Siriporn K. (2014) Supporting Student's Conceptual Development of Light Refraction by Simulation-based Open Inquiry with Dual-situated Learning Model. Jurnal Computer Education. Springer.

[18] Wibowo, F. C., Suhandi, A., Rusdiana, D., Ruhiat, Y., Darman, D. R., Samsudin, A. (2017). Effectiveness of Microscopic Virtual Simulation (MVS) for Conceptualizing Students' Conceptions on Phase Transitions, Advanced Science Letters Vol. 23, (2), pp. 839 $-843$

[19] Johan, H., Suhandi, A., Wulan, A. R., Sipriyadi, Herawati, A. (2018). Enhancing Mastery of Earth Science Concept of prospective Physics Teachers Through Interactive Conceptual Instruction Supported by Visualization and Grads, JurnalPendidikan IPA Indonesia (JPII), 7 (4), 435-441.

[20] Fratiwi, N. J., Samsudin, A., Costu, B. (2018). Ehancing K-10 Students Conceptions Through Computer Simulations-Aided PDEODE*E (CS-PDEODE*E) on Newton's Laws, JurnalPendidikan IPA Indonesia (JPII), 7 (2), 214-223.

[21] Syahroni, M. W., Dewi, N. R., Kasmui. (2016). The Effect of Using Digimon (Science Digital Module) With Scientific Approach at The Visualization of Students' Independence and learning Results, JurnalPendidikan IPA Indonesia (JPII), 5 (1), 116-122.

[22] Harrison, A. G. (1993). A review of textbook analogies for the refraction of light: Proceedings of 18th annual conference of the Western Australian science education association. Perth Western Australia (20-28).

[23] Harrison, A. G. \&Treagust, D. F. (1993). Teaching with analogies: A case study in grade 10 optics. Journal of 
research in science teaching. 30, 1291-1307.

[24] Aykutlu, I., \&Şen, A.I. (2011). Using analogies in determining and overcoming high school students' misconceptions about electric current. Necatibey Faculty of Education Electronic Journal of Science and Mathematics Education, 5(2), 221-250.

[25] Gentner, D., \& Smith, L. (2012). Analogical reasoning. In V.S. Ramachandran (Ed.) Encyclopedia of Human Behavior (2nd Ed.). pp. 130-136. Oxford, UK: Elsevier.

[26] Chiu, M.H., \& Lin, J.W. (2005). Promoting fourth graders' conceptual change of their understanding of electric current via multiple analogies. Journal of Research in Science Teaching, 42(4), 429-464.

[27] Karadoğu., Z. (2007). The Effect of Using Analogy in Primary School Science and Technology Lesson on Success and Attitude (Unpublished Master Thesis).YüzüncüY1l University Institute of Social Sciences, Van.

[28] Dilber, R., Duzgun, B. (2008), Effectiveness of Analogy on Students' Success and Elimination of Misconceptions, Lat. Am. J. Phys. Educ. Vol. 2, No. 3, Sept. 2008

[29] DemirciGüler, M.P. (2007). Analogies used in Science Teaching, The investigation of effect of analogy on students' achievement, attitude and knowledge retention. Unpublished PhD Thesis, Gazi University, Institute of Educational Sciences, Ankara.

[30] Wong, E.D. (1993). Self-generated analogies as a tool for constructing and evaluating explanations of scientific phenomena.J. of Research in Science Teaching, 30, 367-380.

[31] Ivowi, U.M.O. (1983). Achievement level of in understanding physics concepts in secondary schools. Journal of Research in Curriculum, 1(2), 23-34.

[32] Ogbeba, J., Odoh, C. O., and Adeke, A. S. (2014). Students' learning styles, gender and their effects on physics students' achievements in senior secondary schools Journal of Scientific Research and Studies Vol. 1(5), pp. 73-80.

[33] [Piraksa,C., Srisawasdi, N., Koul, R. (2014). Effect of Gender on Students' Scientific Reasoning Ability: A Case Study in Thailand, Procedia - Social and Behavioral Sciences 116 (2014) 486 - 491. 